\title{
Performance of Anaerobic Baffled Reactor with Three Compartments in Removal of COD of Wastewater of Chilly Sauce
}

\author{
Indro Sumantri ${ }^{1 *}$, B. Budiyono ${ }^{2}$, P. Purwanto ${ }^{2}$ \\ ${ }^{1}$ Doctoral Program of Chemical Engineering, Faculty of Engineering, Diponegoro University, Semarang - Indonesia \\ ${ }^{2}$ Department of Chemical Engineering, Faculty of Engineering, Diponegoro University, Semarang - Indonesia
}

\begin{abstract}
The objective in this study is to examine the performance of each compartment of the number of compartments of anaerobic baffled reactor (ABR) to the COD removal of the chilly sauce wastewater. Three-compartments of ABR were conducted in this experiment with the total volume of $60 \mathrm{l}$. ABR is very suitable for processing waste water with high content of COD. Wastewater conducted in this research is a degradable chilly sauce synthetic and high content of organic compounds. While the COD parameter is the main parameter to indicate the achievement of wastewater treatment plant. Stepwise in the research starting with the preparation of raw materials such as sample preparation of synthetic wastewater and preparation of activated sludge. Variable used is the time digestion in the ABR, sludge volume (50\% and $70 \%)$, and initial COD concentrations $(6000-14000 \mathrm{mg} / \mathrm{L})$. The response is observed up to 7 days process. For a load of organic compounds, the first compartment has high degree of decomposition of organic compounds than 2nd and 3rd, it is shown that the COD removal the second and third compartment increase insignificantly compare the first compartment. As for the different height of the activated sludge indicated that for organic load of of $6170 \mathrm{mg} / \mathrm{L}$ up to $14265 \mathrm{mg} / \mathrm{L}$, the first compartment has removal efficiency $79-73 \%$, in the second compartment is $81-75 \%, 81-77 \%$ and third compartment.
\end{abstract}

\section{Background}

Chilly sauce is a complement food with basic ingredients of chilly, it has long been known as an evocative and appetite enhancer. Recent progress of the times, the chilly sauce is now not only produce in traditional process with a simple tool, but it has also been available in the form of ready-made chilly factory output. In Indonesia, there are about 24 companies that produce chilly sauce. The number of company increased when compared in 2003 with number of 16 companies. The number of these companies indicated growing production of chilly sauce in Indonesia which means it also increases the amount of waste generated. Wastewater from the production process resulting from the leaching chilly feedstock, washing equipment, washing of the bottle or packaging. The content of the wastewater is generated mostly organic compound with COD of $14,000 \mathrm{mg} / \mathrm{L}$. Before the wastewater released into the environment, it must be treated through wastewater processing in order to fulfill the threshold value in accordance with the standard quality according to the regulation of Central Java Province (number 5 in 2012) for the chilli sauce that is of $150 \mathrm{mg} / \mathrm{L}$.

Wastewater treatment can be done in physics, chemistry, and biology. Biological wastewater treatment can take place in two main conditions, namely aerobic and anaerobic. In the treatment of organic wastewater on anaerobic condition can utilize activated sludge i.e. suspension biological or microbial mass which is a very active to degrade dissolved organic materials. According to [1], activated sludge technology able to remove COD (chemical oxygen demand) of $76 \%$ with retention time for 6 days. The wastewater with COD content is greater than $4000 \mathrm{mg} / \mathrm{L}$ usually use anaerobic process. On the anaerobic process, micro organisms do not require or less oxygen to treat wastewater. If in terms of energy consumption, the aerobic process will require a lot more energy electricity while the anaerobic process is assessed more effectively and efficiently.

The effort to obtain intensive contact wastewatersludge active is intended so that the waste water residence time became shorter so that will save land for anaerobic reactor [2]. In addition to the effort to get intensive contacts, another attempt was with the optimization of the active sludge whose performance can be improved with the addition of micro-nutrients [3].A small number of compounds that are included in the categories of micro nutrient elements such as nickel, iron, molybdenum, cobalt, copper and zinc that are added into the anaerobic treatment system gives a positive performance against a decline in the levels of organic compounds wastewater loads and resistant to change [4].

* Corresponding author: indrotekim@yahoo.com 


\section{Research Method}

\subsection{Raw Material Preparation}

Raw material wastewater is synthetic wastewater and is set up by dissolved of certain quantity of chilly sauce to the distilled water and this synthetic wastewater is analyzed to obtain the quantity of COD content. While activated sludge obtained from small-scale industrial. This sludge is seeding for two weeks with addition of nutrient of micro organisms with proportion of COD : $\mathrm{N}$ : P of $300: 5: 1$ and also addition of Calcium ion of 40 $\mathrm{mg} / \mathrm{L}$ to prevent the alkalinity.

\subsection{Experiment equipment}

A lab-scale ABR bioreactor with total volume of $60 \mathrm{~L}$ was fabricated using transparent plexi glass sheets and designed has 3-pairs down and upflow, the dimension of the $\mathrm{ABR}$ is $60 \mathrm{~cm}$ of length, $25 \mathrm{~cm}$ of wide, $40 \mathrm{~cm}$ of height, $10 \mathrm{~cm}$ of distance between baffles, $1,5 \mathrm{~cm}$ of distance of baffle and bottom reactor. The ABR consisted of three equal compartments and each compartment had a pair of baffles of downflow and upflow (hanging and standing baffles) and sample ports.

The temperature difference of inside reactor, due to the changes in the temperature during the day and night was less than $3^{\circ} \mathrm{C}$. Therefore, the reactor did not require cooling or heating system to maintain the temperature. A peristaltic pump was used to feed the ABR with synthetic wastewater.

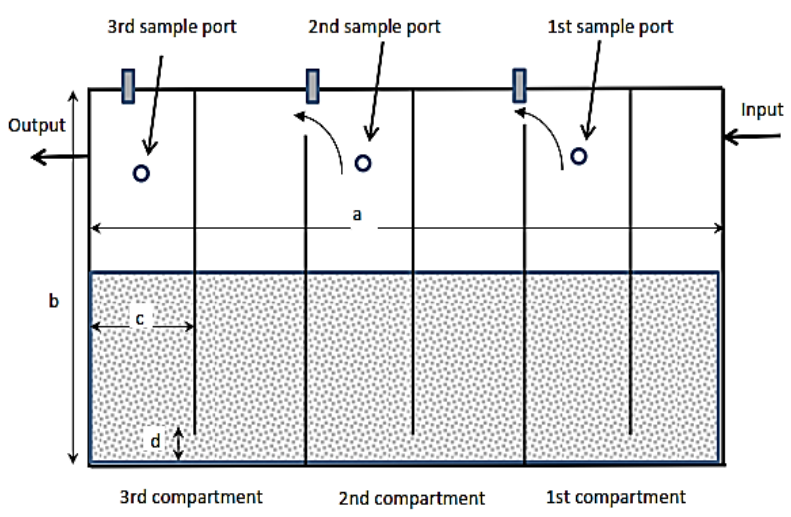

Fig. 1. Diagram of the anaerobic baffled reactor $(A B R)$ and its baffles with dimensions $(\mathrm{cm}) \mathrm{a}=60 \mathrm{~cm} ; \mathrm{b}=40 \mathrm{~cm} ; \mathrm{c}=105$ $\mathrm{cm} ; \mathrm{d}=1.5 \mathrm{~cm}$; wide: $25 \mathrm{~cm}[5]$

\subsection{Experiment sets up}

Experiments conducted with volumetric feed rate of 20 $\mathrm{L} /$ day by using peristaltic pump, initial $\mathrm{pH}$ is 7-7,5. Addition of trace elements per gram COD (Co : $500 \mu \mathrm{g}$, $\mathrm{Cu}: 300 \mu \mathrm{g}, \mathrm{Fe}: 4000 \mu \mathrm{g}$, Mo : $150 \mu \mathrm{g}$, Ni : $6000 \mu \mathrm{g}$, and $\mathrm{Zn}: 600 \mu \mathrm{g})$. Room temperature, atmospheric pressure, calsium ion $(40 \mathrm{mg} / \mathrm{L})$. The research variables are the height of activated sludge (50 and $70 \%)$ and initial COD concentration $(6000,10000$, and 14000 $\mathrm{mg} / \mathrm{L})[3]$.

\subsection{Parameter response}

Parameter observed for this research is COD. The selection of COD parameter is based on the quantity of the organic material could be quantity as $\operatorname{COD}[6]$.

\section{Results and discussion}

\subsection{Performance of ABR with $50 \%$ sludge height and various COD contents}

The content of the COD conducted this research is: 6170 $\mathrm{mg} / \mathrm{L}, 10170 \mathrm{mg} / \mathrm{L}$, and $\mathrm{mg} / \mathrm{L} 14265$. Observations of COD content done for each day until the seventh day with the consideration that the wastewater is easily degraded hence, the retention time is short. Performance of $\mathrm{ABR}$ with three-pair compartments for various contents of wastewater were observed for each compartment to show the COD removal: for first compartment $(71.83-67.29-62.90 \%)$, second compartment $(73.31-72.20-65.70 \%)$, and third compartment (74.55 - 74.88-68.57\%).

For the condition of $50 \%$ height of activated sludge, the higher the concentration of wastewater will be the lower removal of COD in this anaerobic process. Increasing the amount of wastewater will increase the load of activated sludge to degrade the organic substances, actually the activity of the micro organisms indicated advance in degradation of the organic substances but in the term of percentage of COD removal, it showed a decrease with an increase in the load of wastewater. The efficiency of the COD removal for first to second and third compartments indicated less significant improvement, with total similar amount of activated sludge in each compartment the COD removal of first to second and third compartments are very small (less than 5\%). This indicated that with the increasing load of wastewater is required sufficient amount of microorganisms to enhance degradation of organic compounds. The presence of a preservative substance in chilly sauce affect the performance of ABR because preservatives will influence the performance of microorganisms. The addition of the preservatives substance into the food and drink is to maintain freshness and prevent food damage or food ingredients by suppress the growth of micro-organisms (Maier et al., 2010; Porsby et al., 2008). The first compartment is a compartment with a heavy load because the first contact of wastewater and activated sludge occurred in this compartment. The COD removal is caused by anaerobic bacteria activity on the activated sludge [7]. These bacteria growth optimum at $\mathrm{pH}$ neutral. These bacteria work with degradation of glucose. The value of COD removal indicated that organic load which degraded by microorganisms in the activated sludge. Increasing the 
amount of bacteria will affect to the greater organic load that can be degraded by microorganisms. This is due to amount of substrate contacted with the microorganisms.
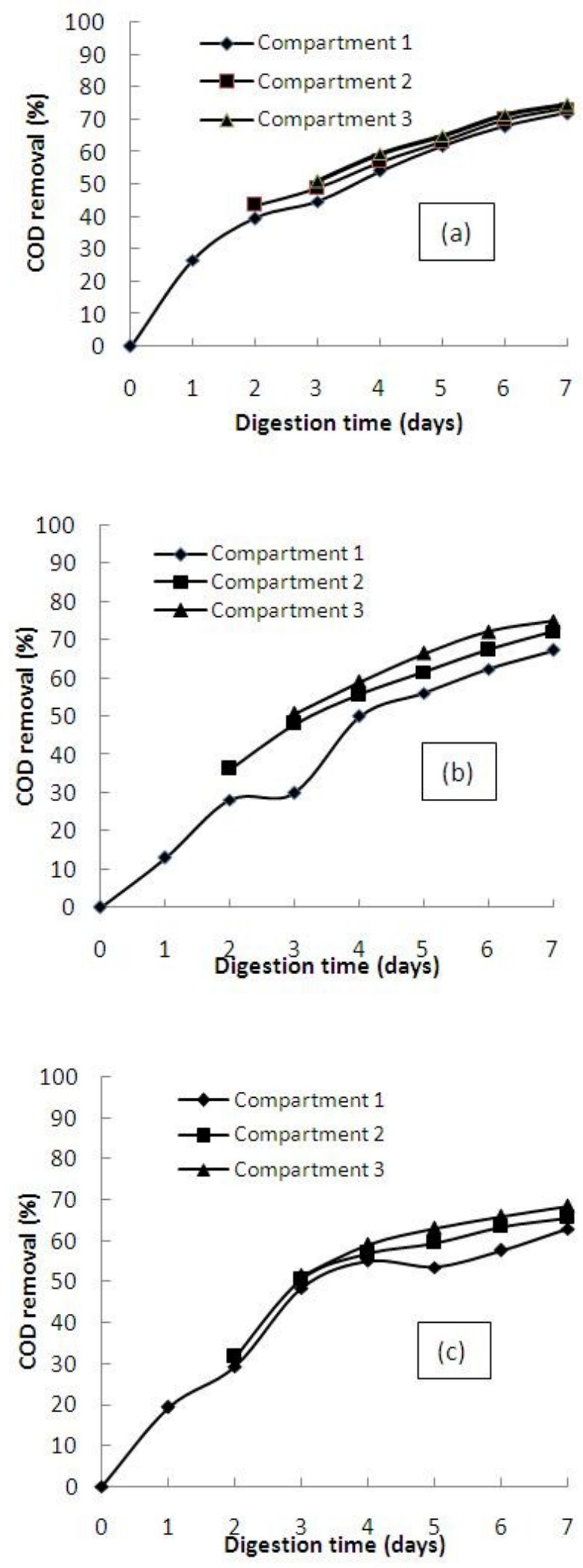

Fig. 2. Performance of $A B R$ at $50 \%$ sludge height with various COD content (a) $6170 \mathrm{mg} / \mathrm{L}$, (b). $10.127 \mathrm{mg} / \mathrm{L}$, and (c). $14265 \mathrm{mg} / \mathrm{L}$
While, even at the shortest retention time of 3 days the system can achieve high performance as above $77.3 \%$ COD removal [8], also an retention time of $4.25 \mathrm{~d}$, the total COD removal efficiencies reached $88.7 \%$ [9]. Attributed to the incomplete anaerobic digestion. The main reason for the relatively poor efficiency was the accumulation of suspended solids in the sludge blanket resulting from suspended solids overload in this condition. Consequently, it caused sludge washout, followed by a decrease in COD removal from 95.13 to $78.01 \%$. It was noted that after the occurrence of sludge washout, the reactor efficiency was observed [9].

\subsection{Performance of ABR with $70 \%$ sludge height and various COD contents}

Figure 3 (a)-(c) indicated the performance of ABR with $70 \%$ height of activated sludge. It is generally shown that COD removal until the third day shows a sharp removal in rates, $60 \%$ of COD can be removed. Compared to $50 \%$ height activated sludge then the COD removal for $70 \%$ height of activated sludge is much larger. This is because the more sludge is utilized then the more microorganisms obtained, so, that will degrade on the organic compounds in the wastewater [10]. The amount microorganisms availability will be increased degradation of the organic compounds, hence, the COD content in wastewater will be getting smaller. The availability of food sources of microorganisms will enhance the growth and amount the number of microorganisms, hence, decomposition of organic compounds in wastewater is also faster, it causes a decrease in the value of COD content sharply[11].

Increased efficiency of the first compartment to the second and third compartments is small and insignificant. The small increment of improvement in the efficiency of the COD removal in the second and third compartment is due to the short retention time, hence, this three compartments are nearly have the same composite on. It can be said that the high flow rate or short liquid retention time will result in the three compartments have similar composition or the same as the type of Upflow Anaerobic Sludge Blanket (UASB) reactors. Figure 3 shows that for all three types of COD content of wastewater have shown that the stationary condition has almost achieved, this can be seen from the small enhancement of the efficiency of the COD removal. The correlation between the number of activated sludge with the efficiency of the COD removal is very clearly indicated that the higher number of activated sludge then it will be more and more organic compounds are degraded. Total COD removal is between $77,53-82,06 \%$. The value of the COD removal is lower if compared to that done by previous researchers $[8,9]$. The presence of a preservative in chilly sauce played an important role so that the efficiency of decreasing COD becomes smaller compared to previous research. 



Fig 3. Performance of $A B R$ at $70 \%$ sludge height with various COD content (a) $6170 \mathrm{mg} / \mathrm{L}$, (b). $10.127 \mathrm{mg} / \mathrm{L}$, and (c). 14265 $\mathrm{mg} / \mathrm{L}$

\section{Conclusions}

The amount of activated sludge plays an important role in the COD removal, the higher of activated sludge the higher the efficiency of degradation. Three compartments observed for the COD parameter has concentration is closed to each compartment, it showed that the retention time of wastewater in the $A B R$ is a main factor to be controlled.

\section{Acknowledgement}

We would like to thank the UNDIP financial scheme of APBN DPA SUKPA LPPM Universitas Diponegoro Year 2017

\section{References}

1. Setiyani. . "Bioreaktor Pengolahan Limbah Cair". Pusat Antan, Universitas Bioteknologi, Institut Teknologi Bandung (2010).

2. G.F Zhu, Li, J. Z., Wu, P., Jin, H. Z., \& Wang, Z. Bioresource Technology, 99(17), 8027-8033.(2008).

3. J. Ma, L.J. Mungoni, W. Willy Verstraete, M. Carballa, Bioresource Technology 100 (2009) 34773482, (2009).

4. K. Izumi, Y. Okishio, N. Nagao, C. Niwa, S. Yamamoto, \&T. Toda, International Biodeterioration \& Biodegradation, 64(7), 601608,(2010).

5. I. Sumantri, Purwanto, and Budiyono.,AIP Conference Proceedings 1699, 050017 (2015).

6. APHA. Standard methods for the examination of water and wastewater. 21 st edition, 2005. Washington, DC

7. K. Dhamodaran\& S.K. Ajay, J.Env Chem Eng.Sci. vol.2, pp.1821-1830, (2014).

8. M. Faisal \&H. Unno, Biochemical Engineering Journal, 9(1), 25-31,(2001).

9. M. Pirsaheb, M. Rostamifar, AM. Mansouri, a.a.L. Zinatizadeh, \&K. Sharafi, Journal of the Taiwan Institute of Chemical Engineers, 47, 137-148.(2015).

10. Suyasa, I Wayan Budiarsa dan I Made Arsa.2013. Penurunan Kadar COD Air Limbah Industry Jamu menggunakan Lumpur Aktif.

11. J.P. Guyer . Introduction to Secondary Wastewater Treatment (2011).. 